\title{
Multicriteria Method in Data Envelopment Analysis: an application to measure the performance of the instrument of charging for water in the State of Ceará basins
}

\author{
Método Multicritério em Análise por Envoltória de Dados: uma aplicação para medir o \\ desempenho do instrumento da cobrança pela água nas bacias do Estado do Ceará
}

\author{
Marcus Vinicius Sousa Rodrigues ${ }^{1}$, Marisete Dantas de Aquino², Antônio Clécio Fontelles Thomaz ${ }^{3}$ and \\ Rejane Felix Pereira ${ }^{4}$ \\ ${ }^{1}$ Universidade Federal Rural do Semi-Árido, Angicos, RN, Brazil \\ ${ }^{2}$ Universidade Federal do Ceará, Fortaleza, CE, Brazil \\ ${ }^{3}$ Universidade Estadual do Ceará, Fortaleza, CE, Brazil \\ ${ }^{4}$ Universidade da Integração Internacional da Lusofonia Afro-Brasileira, Redenção, CE, Brazil
}

E-mails: marcus@ufersa.edu.br (MVSR), marisete@ufc.br (MDA), clecio@larces.uece.br (ACFT), rejanefp@gmail.com (RFP)

Received: May 27, 2016 - Revised: August 10, 2016 - Accepted: September 16, 2016

\begin{abstract}
The water policies adopt management instruments, among which the charge for water use stands out. Because there are many factors that can be used in an analysis of the efficiency of this management instrument in a watershed, it is necessary to use a scientific methodology for multi-criteria analysis. The aim of this study was to analyze the performance of charging for the use of raw water in the river basins of Ceará State in the main categories of use (industrial, supply and irrigation) using the methodology for data envelopment analysis (DEA) and the BBC model, with the help of computational tool SIAD (Integrated System for Decision Support) to designate the most and the least efficient units in order to improve the management of these resources. In this study, the industry units stood out, shwoing an average efficiency of $57.67 \%$, followed by the public supply with an average efficiency of $22.69 \%$ and irrigation with an average efficiency of $11.78 \%$. The charge for the use of water in the Litoral basin, in the industrial sector, stood out as the most efficient unit of the whole study, as the least efficient unit was the basin of the Litoral, in the irrigation sector.
\end{abstract}

Keywords: Multicriteria analysis; Data envelopment analysis; Charging of the water.

\section{RESUMO}

As políticas de recursos hídricos adotam instrumentos de gerenciamento, dentre os quais se destaca a cobrança pelo uso da água. Por existir múltiplos fatores que podem ser utilizados em uma análise da eficiência desse instrumento de gerenciamento em uma bacia hidrográfica, faz-se necessário o uso de uma metodologia científica de análise multicritério. O objetivo deste estudo foi analisar o desempenho da cobrança pelo uso da água bruta nas bacias hidrográficas do Estado do Ceará nas principais categorias de uso (industrial, abastecimento e irrigação) utilizando a metodologia de Análise por Envoltória de Dados (AED) e o modelo BBC, com o auxilio da ferramenta computacional SIAD (Sistema Integrado de Apoio à Decisão) para designar as unidades mais eficientes e menos eficientes a fim de aperfeiçoar a gestão desses recursos. Neste estudo, as unidades da indústria se destacaram, apresentando uma eficiência média de 57,67\%, seguida pelo abastecimento público com uma eficiência média de 22,69\% e a irrigação com uma eficiência média de $11,78 \%$. A cobrança pelo uso da água da bacia do Litoral, no setor industrial, se destacou como a unidade mais eficiente de todo o conjunto estudado, já a unidade menos eficiente foi a bacia do Litoral, no setor irrigação.

Palavras-chave: Análise multicritério; Análise por envoltória de dados; Cobrança de água. 


\section{INTRODUCTION}

The charge for water use is provided for by law since the Decree 24643, of July $10^{\text {th }}, 1934$, known as the Water Code, which contained in its text current concepts such as user-payer and the polluter-payer principles. However, these concepts have not been put into practice. Thus, the charging for water instrument would only be formally established by Federal Law $n^{\circ}$ 9433, of January $8^{\text {th }}$, 1997 , popularly known as the Water Law.

It is important to note that the State of Ceará was one of the states that anticipated the Union by establishing a policy of water resources, through the Law n 11996 of July 24 $4^{\text {th }}, 1992$. This law was replaced, afterwards, by Law n 14844 of December $28^{\text {th }}, 2010$, which disposes of the State of Ceará Policy of Water Resources - PERH.

Among the instruments cataloged in Law n ${ }^{\circ} 14844 / 2010$, the charge for the use of raw water is highlighted. According to Silveira, Forgiarini and Goldenfum (2009), the charge for the use of water resources still aims that this resource may be used in a rational way for its users, in order to meet the principles of the sustainable development.

Many are the factors (or criteria) that can be used to measure the performance (or efficiency) of the implementation of the charge for the use of water, being necessary the use of multi-criteria analysis techniques.

According to Athanassopoulos (2012), the evaluation of efficiency can be considered as a major concern by part of the managers and the development of tools for this analysis has expanded greatly in the recent years.

The multi-criteria analysis technique used in this research was the data envelopment analysis (DEA). According Banaeian, Omid and Ahmadi (2011), this technique can be used in a set of production units, usually called decisions making units (DMUs) in order to classify them according to their performances.

The DEA can be defined as a mathematical programming technique used to measure the performance (or efficiency) of production units, or DMUs, which convert multiple entries, or inputs, in outputs, or outputs (MIRDEHGHAN; FUKUYAMA, 2016).

According to Adler and Yazhemsky (2010), a DMU can represent any number of organizations or departments that essentially perform the same task with the same set of variables.

The objective of this study is to select the most significant factors related to the instrument of charging for water use, in order that they are used for applying the Data Envelopment Analysis to assess the relative efficiency of the instrument of the main categories of use (industry, supply and irrigation) of all the State of Ceará basins, obtaining in that way a general diagnosis of this instrument efficiency.

The importance of these selected sectors is due to the fact that they together consume a total of 320 million $\mathrm{m}^{3}$, representing $98 \%$ of consumed volume, with a billing of $\mathrm{R} \$ 58$ million, which represent $99 \%$ of the total billed. In relation to the grant, the three sectors together have 341 million $\mathrm{m}^{3}$ granted, representing $95 \%$ of all granted volume in the whole state (RODRIGUES, 2014).

\section{THE CHARGE FOR WATER USE IN THE STATE OF CEARÁ}

The charge for water in the state of Ceará was accomplished by Decree $n^{\circ} 24264$ of November $12^{\text {th }} 1996$, in which were initially charged withdrawals of water intended to be used in the industries and in the concessionary enterprises of drinking water service. According to Rodrigues and Aquino (2014), only in 2004 this charge was applied for other use purposes, namely: industry, public water supply, irrigation, fish farming, mineral water and other categories.

The institution responsible for the billing and the collection of funds from the charging is the Water Resources Management Company of the State of Ceara (COGERH), which acts as an agency for all Ceará basins (FINKLER et al., 2015). The charge for raw water, both on the surface and underground, is based on actual consumption, with the following model:

$T(u)=T_{e f} V_{e f}$

where $\mathrm{T}(\mathrm{u})$ is the fare paid by the user, in $\mathrm{R} \$ ; \mathrm{T}_{\text {ef }}$ is the standard consumption rate at $\mathrm{R} \$ / \mathrm{m}^{3}$; and, $\mathrm{V}_{\mathrm{ef}}$ is the volume actually consumed during the month by the user, in $\mathrm{m}^{3}$. According to Aquino, Gomes and Souza Filho (2013), the tariff value and the billing criteria are updated by the state government decree.

It is currently in force the Decree $n^{\circ} 31195$ of April 16 ${ }^{\text {th }}$, 2013, which provides about the charging and establishes the tariff values of consumption to be charged in the Ceará basins. In the Table 1 the tariff are shown, $\mathrm{T}_{\mathrm{ef}}$, for each user sector, in $\mathrm{R} \$ / 1,000 \mathrm{~m}^{3}$.

In addition to the charge for the actual consumption of raw water, the Law $n^{\circ} 14844 / 2010$ also guides the charging for effluent discharge into the water bodies of Ceará. However, up to now, the charging of this use category has not been accomplished yet.

It is worth to emphasize that according to the Decree $n^{\circ} 31195 / 2013$, the charge for the raw water must pass the grant of the water use rights, issued by the Water Resources State Department - SRH (CEARÁ, 2013). It means, by law, that every user charged for the use of raw water in the state must have a grant which authorizes to carry out the extraction of water in a fountain-head.

However, according to Rodrigues (2014), it is noticed the existence of billed users, those who pay for water consumption, who do not have issued grants. Thus, this fact can be considered as a failure or inefficiency of the management system of water resources of the State, especially the water resources monitoring instrument.

\section{DATA ENVELOPMENT ANALYSIS}

Production can be understood as the act of transforming inputs into outputs with the help of technology (PRADHAN; KAMBLE, 2015). Then, in a productive process the applied inputs in the production should be used as best as possible, so that there is no excess.

In this way, the productivity rate can be used to compare efficiency of several production units. For Honglan, Ruyun and Xiaona (2014), the productivity is an important indicator to measure 
Table 1. Rate for the use of raw water in the State of Ceará.

\begin{tabular}{|c|c|}
\hline Uses/Category & $T_{\text {ef }}$ \\
\hline \multicolumn{2}{|l|}{ Public Supply } \\
\hline Metropolitan Region of Fortaleza & 105.36 \\
\hline Other regions - without adduction of COGERH & 34.76 \\
\hline Other regions - with adduction of COGERH & 318.51 \\
\hline \multicolumn{2}{|l|}{ Industry } \\
\hline without adduction of COGERH & 459.65 \\
\hline with adduction of COGERH & $1,581.25$ \\
\hline \multicolumn{2}{|l|}{ Irrigation } \\
\hline From 1,440 to $18,999 \mathrm{~m}^{3} /$ month - without adduction of COGERH & 1.00 \\
\hline From $19,000 \mathrm{~m}^{3} /$ month - without adduction of COGERH & 3.00 \\
\hline From 1,440 to $46,999 \mathrm{~m}^{3} /$ month - with adduction of COGERH & 7.84 \\
\hline From $47,000 \mathrm{~m}^{3} / \mathrm{mês}$ - with adduction of COGERH & 12.55 \\
\hline \multicolumn{2}{|l|}{ Fish Farming } \\
\hline Excavated Tank - without adduction of COGERH & 3.20 \\
\hline Excavated tank - with adduction of COGERH & 12.55 \\
\hline Net tank & 38.11 \\
\hline \multicolumn{2}{|l|}{ Shrimp Farming } \\
\hline without adduction of COGERH & 3.20 \\
\hline with adduction of COGERH & 12.55 \\
\hline \multicolumn{2}{|l|}{ Other uses } \\
\hline without adduction of COGERH & 105.70 \\
\hline with adduction of COGERH & 319.53 \\
\hline mineral water and drinkable & 459.65 \\
\hline
\end{tabular}

\section{Tef $=$ tariff in $\mathrm{R} \$ / 1,000 \mathrm{~m} 3$.}

Source: Ceará (2013).

the proficiency level of one production unit. Thus, the concept of efficiency is related to the comparison of productivity between the different units, being, consequently a relative measurement.

The data envelopment analysis (DEA) can be considered a non-parametric technique, since it does not require a functional relationship between the inputs and the outputs (CHERCHYE; ROCK; WALHEER, 2016).

For Barbosa and Bastos (2014), the DEA methodology enables to conduct an analysis of comparative efficiency for a number of production units, demonstrating how each unit is operating in relation to other in the group, obtaining then a complete diagnosis of the whole set.

According to Qingxian, Yan and Liang (2016), the DEA by approaching this methodology, it is possible to detect the inefficiency of resource use in a production system.

The DEA is used to build a linear border of parts, called the efficient border, whose vertices are formed by efficient units (PARK et al., 2015). For Alper, Sinuany-Stern and Shinar (2015), the methodology divides the units into two groups: the efficient and inefficient one.

The construction of this boundary uses for this the input factors and the evaluated output of each unit and then provides a measure of relative efficiency for each unit.

As stated by Rodrigues, Aquino and Thomaz (2015), “[...] the best relations outputs/inputs are considered more efficient and are located at the efficient border, while the less efficient ones will be located in the area below this curve, called the convex wrap".

The units evaluated in DEA are compared according to the efficiency concept of Farrel, which is defined as the ratio of the weighted sum of outputs and the weighted sum of inputs of each unit (DOTOLI et al., 2015). Therefore, mathematically, the efficiency for " $m$ " inputs and "s" outputs is given by Equation 2 :

Efficiency $=\sum_{i=1}^{s} U_{i} Y_{i} / \sum_{j=1}^{m} V_{j} X_{j}$

where: $U_{i}$ is the weight of the $i$-th output, $Y_{i}(i=1, \ldots, s)$; and, $V_{i}$ is the weight of the $j$-th input, $X_{i}(j=1, \ldots, m)$.

The efficient units, called benchmark, suit as reference for other units considered inefficient. As Gomes Júnior, Soares de Mello and Ângulo Meza (2013) state, the DEA methodology calculates targets to be achieved by the inefficient units in order to make them become effective.

The units showed below the efficiency border, seen as inefficient, should be designed towards the efficient frontier, achieving in this way their efficient partner. A unit considered inefficient can reach the efficient frontier in two distinct ways:

- Through the minimization of entry (inputs), keeping constant the products (outputs), called input-oriented.

- Through the maximizing of products (outputs), keeping constant the entries (inputs), called output-oriented.

According to Périco, Rebalatto and Santana (2008), an organization's efficiency study involves necessarily the question of the efficient border, and an organization will be closer to that boundary when it reaches higher productivity, consuming less resources.

There are two basic models of data envelopment analysis (DEA): the CCR model, working with constant returns to scale; and the BCC model, which allows variable returns of scale, resulting in a border formed by convex combinations of efficient units, and being then the model used in this study. 
It is important to highlight that the DEA methodology began with the work published by Charnes, Cooper and Rhodes (1978), which aimed to analyze school programs efficiency in Texas State - USA. This model became known as CCR (initial of the authors: Charnes, Cooper and Rhodes), and it was initially developed with an orientation to input, working with continuous scales returns.

In Banker, Charnes and Cooper (1984), BCC model (initials of the authors) has been developed that admit variable returns of scales and it is the most suitable for units with inputs and outputs of many different sizes.

It is worth to remember that the assumption of continuous scales returns of the CCR model can be relaxed with the addition of a free variable, $U_{*}$ for guidance to input and $V_{*}$ to guidance to output, as it will be seen below.

For " $n$ " DMUs, similar with each other, using " $m$ " inputs and "s" outputs in a BCC model with orientation to input, the weights of inputs and outputs of an object unit, $\mathrm{DMU}_{\mathrm{O}}$, are determined by the resolution of Equation 3 .

$$
\max E_{f O}=\sum_{i=l}^{s} U_{i} Y_{i O}+U_{*}
$$

In what:

$$
\sum_{j=1}^{m} V_{j} X_{j O}=1
$$

$$
\sum_{i=1}^{s} U_{i} Y_{i k}-\sum_{j=1}^{m} V_{j} X_{j k}+U_{*} \leq 0,(k=1, \ldots, n)
$$

$$
U_{i} \geq 0(i=1, \ldots, s) ; \quad V_{j} \geq 0(j=1, \ldots, m) ; U_{*} \in \mathbb{R}
$$

Where: $\mathrm{E}_{\mathrm{fo}}$ is the relative efficiency $\mathrm{DMU}_{\mathrm{O}} ; \mathrm{Y}_{\mathrm{ik}}$ e $\mathrm{X}_{\mathrm{jk}}$ are the observed quantities of output $i$ of unit $k$ and observed input $j$ of unit k, respectively; $\mathrm{U}_{\mathrm{i}}$ and $\mathrm{V}_{\mathrm{i}}$ are the weights given to the output $\mathrm{i}$ and the input $\mathrm{j}$, respectively; and $\mathrm{Y}_{\mathrm{io}}$ and $\mathrm{X}_{\mathrm{jo}}$ are the quantities of output $i$ and input $j$ of the object unit, respectively.

If the free variable $U_{*}$ would be positive, then, the model shows no decreasing returns to scale (RND), while if the variable would be negative, the model shows itself with no increasing return of scale (RNC). It is important to highlight that the efficiency is achieved through the reduction of inputs.

In DEA modeling for the BCC model, output-oriented, is based on the Equation 7.

$$
\min h_{O}=\sum_{j=1}^{m} V_{j} X_{j O}+V_{*}
$$

In what:

$$
\begin{aligned}
& \sum_{i=1}^{s} U_{i} Y_{i O}=1 \\
& \sum_{i=1}^{s} U_{i} Y_{i k}-\sum_{j=1}^{m} V_{j} X_{j k}+V_{*} \leq 0, \quad(k=1, \ldots, n) \\
& U_{i} \geq 0(i=1, \ldots, s) ; \quad V_{j} \geq 0(j=1, \ldots, m) ; V_{*} \in \mathbb{R}
\end{aligned}
$$

If the free variable $V_{*}$ would be positive, then, the model shows no increasing returns to scale, while if the variable would be negative, the model shows itself with no decreasing return of scale.

\section{MULTICRITERIA METHOD}

Each unit chooses its own set of weights for its factors, in order that the efficiency would be the best possible in comparison to the other evaluated units. In this way, it is possible that a large number of DMUs stay located at the efficient border, showing the little discriminatory capacity of DEA classic models (PEREIRA; SILVEIRA; CHAVES, 2012).

In practice, it is recommended that the number of DMUs analyzed should be at least five times the number of factors (inputs+outputs). Then, in case of impossibility to increase the number of DMUs, it should necessarily reduce the number of evaluation factors. In this way, the method multi-criteria for variable selection can applied in order to select inputs and the most significant outputs for analysis.

According to Ângulo Meza et al. (2007, p. 25), “[...] the methods of variables selection should be seen as instruments to help the decision, which will guide the final choice."

The stage of variables selection is justified if there is always a small amount of units to be evaluated and a large number of factors, such as in this case study.

In Soares de Mello et al. (2004), a model to select factors is proposed where it is considered the best fit to the border, measured by the average efficiency, as the maximum discrimination, measured by the amount of DMUs at the efficient border. This model is called Multicriteria method of variables selection in DEA.

The boundary setting is measured by the set of DMUs average efficiency. It means that, the measurements of average efficiencies are normalized with an interpolation which assigns the value "one" to the biggest extent and "zero" to the smaller average. Thus, the normalized value is identified by SEF (an abbreviation of the term standardize efficiency).

The maximum discrimination is measured by the number of DMUs at the efficient border. Then, the standardization of this measure gives the term SDIS (an abbreviation of the term standardize discrimination), which reaches the value "one" for the smallest number of DMUs at the efficient border and "zero" to the biggest number of efficient DMUs.

According to Soares de Mello et al. (2004), the term S is defined as a weighted sum of SEF and SDIS, with the restriction that the sum of weights would be the same as the unit,

$$
S=\alpha S E F+(1-\alpha) S D I S
$$

In that $0 \leq \alpha \leq 1$

\section{METHODOLOGY}

The model comes from initial input/output, which can either be chosen or calculated by using a criterion suggested by the analyst. To the initial pair (input / outputl) is added a new factor (input or output) and calculated the value of the $S$ term for each case. The variable presenting the highest $\mathrm{S}$ is incorporated into the 
initial pair, forming now a set with three variables. The procedure of incorporating the factor which produces a higher value $S$ is followed until the number of factors does not exceed $1 / 5$ of the number of analyzed DMUs. If, otherwise, the procedure is closed, all factors that should be added to the model were selected.

\section{Decision Making Units (DMU) and evaluation factors}

Currently, the State of Ceará is composed of 12 hydrographic basins, namely: Metropolitan Basin, Acaraú Basin, Upper Jaguaribe Basin, Middle Jaguaribe Basin, Lower jaguaribe Basin, Banabuiú Basin, Coreaú Basin, Curu Basin, Litoral Basin, Salgado Basin, Ibiapaba Mountain Basin and Sertões Crateús Basin. Figure 1 shows the location of the river basins in the State, with their respective areas.

It is important to point out that until 2011 the basins of the Sertões Crateús and Ibiapaba formed the Parnaíba Basin. However, the obtained data for these two basins were still together as the Parnaíba Basin. In this way, the survey considered the State divided into eleven (11) basins, namely: Metropolitana, Curu,
Upper Jaguaribe, Middle Jaguaribe, Lower Jaguaribe, Salgado, Litoral, Acaraú, Coreaú, Parnaíba and Banabuiú.

So, because were considered only the categories of industry, public water supply and irrigation, they are all together 33(thirty-three) analyzed DMUs in the survey, as described in Chart 1. It means, each sector of considered use of a given basin represents a DMU.

All evaluation factors (inputs and outputs) considered in this study are listed in Chart 2.

The values of the proposed evaluation factors for each DMU were obtained from the Water Resources Management Company of the State of Ceara (COGERH) and the Secretariat of Water Resources of Ceará (SRH). The billing report provided by COGERH refers to a period of 12 months (one year) beginning in May 2012 and runs until April 2013. In the meantime, the reports of issued grant, both for surface water as for groundwater, refer to the month of April 2013.

The data on water demands of the main categories of use (industrial, public supply and irrigation) and water availability by watershed were obtained at the SRH.

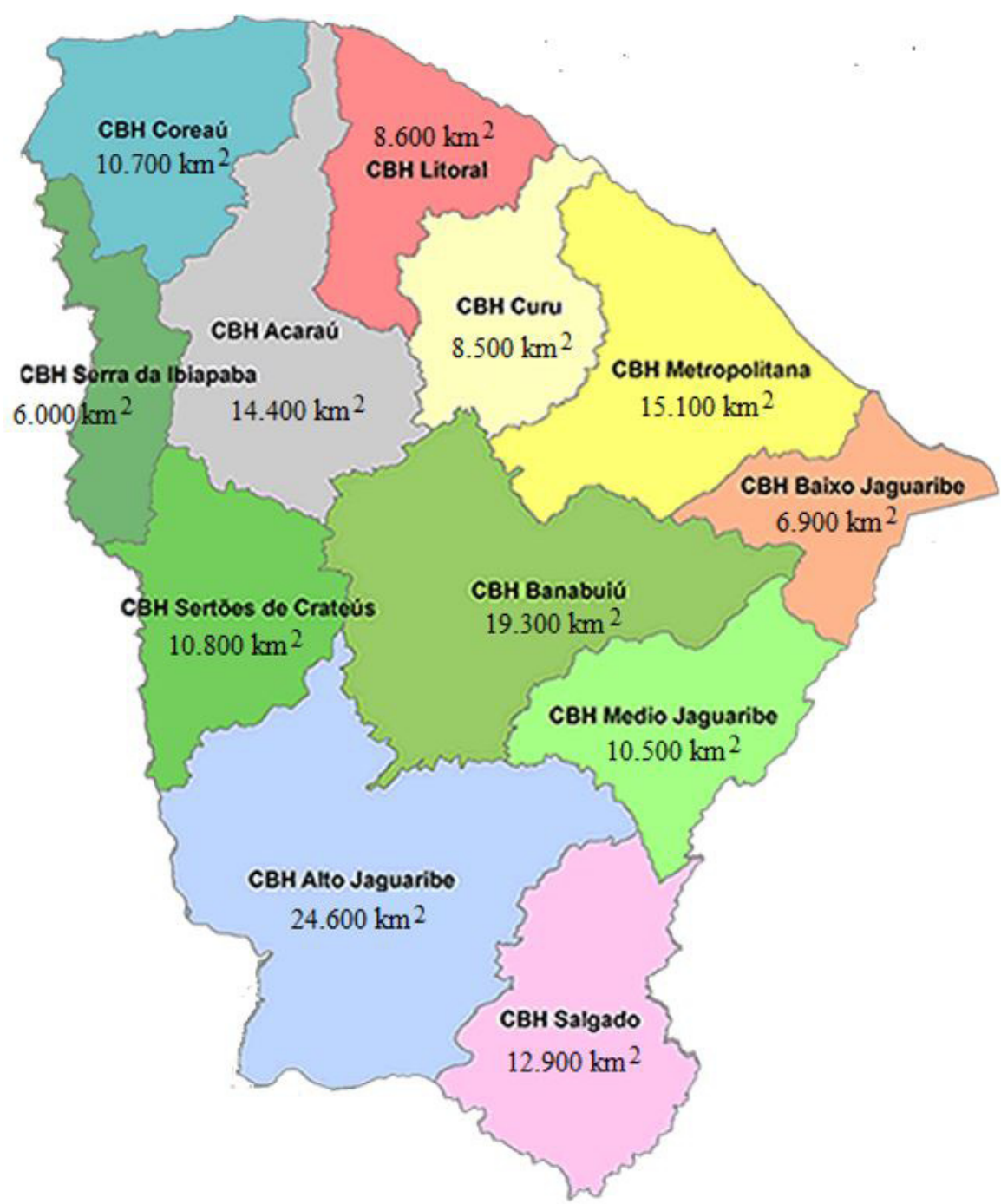

Figure 1. Location of river basins in the State of Ceará. CBH is the hydrographic basins committee.

Source: Rodrigues (2014). 
Multicriteria Method in Data Envelopment Analysis: an application to measure the performance of the instrument of charging for water in the State of Ceará basins

Chart 1. Decision Making Units evaluated in the survey.

\begin{tabular}{|l|l|l|}
\hline \multicolumn{2}{|c|}{ Industry } & \multicolumn{1}{|c|}{ Public supply } \\
\hline DMU1 - Metropolitana Basin & DMU2 - Metropolitana Basin & \multicolumn{1}{c|}{ Irrigation } \\
\hline DMU4 - Curu Basin & DMU5 - Curu Basin & DMU3 - Metropolitana Basin \\
\hline DMU7 - Upper Jaguaribe Basin & DMU8 - Upper Jaguaribe Basin & DMU6 - Curu Basin \\
\hline DMU10 - Middle Jaguaribe Basin & DMU11 - Middle Jaguaribe Basin & DMU9 - Upper Jaguaribe Basin \\
\hline DMU13 - Lower Jaguaribe Basin & DMU14 - Lower Jaguaribe Basin & DMU12 - Middle Jaguaribe Basin \\
\hline DMU16 - Salgado Basin & DMU17 - Salgado Basin & DMU15 - Lower Jaguaribe Basin \\
\hline DMU19 - Litoral Basin & DMU20 - Litoral Basin & DMU18 - Salgado Basin \\
\hline DMU22 - Acaraú Basin & DMU23 - Acaraú Basin & DMU21 - Litoral Basin \\
\hline DMU25 - Coreaú Basin & DMU26 - Coreaú Basin & DMU24 - Acaraú Basin \\
\hline DMU28 - Parnaiba Basin & DMU29 - Parnaiba Basin & DMU27 - Coreaú Basin \\
\hline DMU31 - Banabuiú Basin & DMU32 - Banabuiú Basin & DMU30 - Parnaiba Basin \\
\hline SManin & DMU33 - Banabuiú Basin \\
\hline
\end{tabular}

Source: Authors.

Chart 2. Proposed evaluation factors.

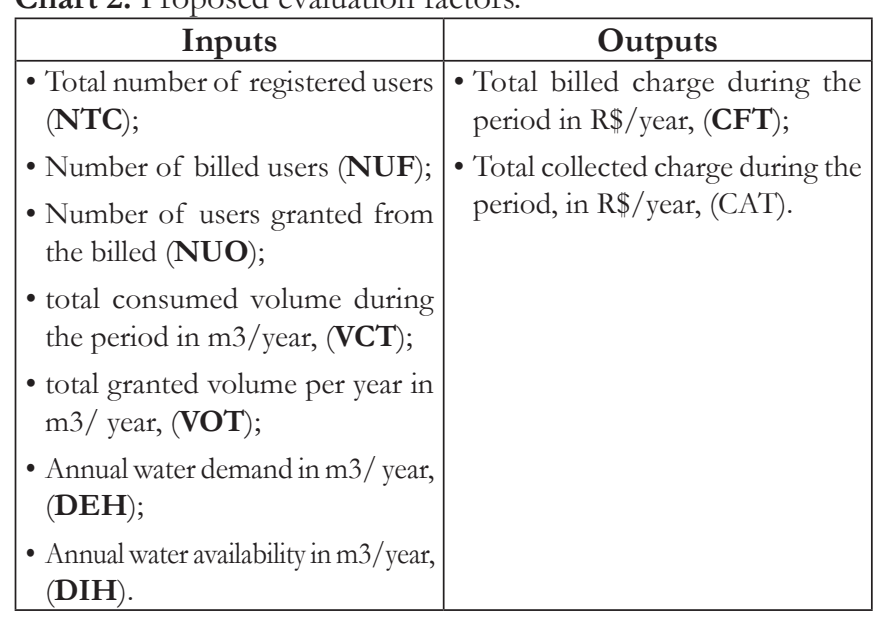

Source: Authors.

\section{Reversed border}

The analyzed DMUs in this study present data with different sizes, as can be seen in Appendix A, then, they tend to have variable scales incomes. In this way, the selected method to measure the efficiencies will be the BCC model, with guidance to the output.

The DEA models often result in a large number of efficient units. Furthermore, due to the mathematical characteristics of the BCC model, the DMUs which have the smaller value of the inputs or a higher value of the outputs are considered as efficient, being called of falsely efficient.

Therefore, the method of the reserved border can be applied to identify and eliminate the efficient units that present with false efficiency. The reserved border consists in consider the outputs as inputs and the inputs as output for each unit, and subsequently it solves the BCC model of the DEA usually with an orientation to input.

According to Ângulo Mezaet al. (2007), the method of reversed border builds a composed efficiency index, defined as the arithmetic average of efficiency in relation to the DEA conventional border, $\mathrm{Ef}_{\text {conv }}$ and the complement of efficiency in relation to the reversed border, $\mathrm{Ef}_{\text {inv }}$. Based in the Equation 12,
$E f_{\text {comp }}=\frac{E f_{\text {conv }}+\left(1-E f_{\text {inv }}\right)}{2}$

Thereafter, the normalization of the composed efficiency is done, dividing the values of Equation 12 obtained in each DMU for the biggest of all composed efficiency measurements. Thus, the normalized composed efficiency, indicated by Ef $\mathrm{form}_{\text {is }}$ defined by Equation 13,

$$
E f_{\text {norm }}=\frac{E f_{\text {comp }}}{\operatorname{Máx}\left(E f_{\text {comp }}\right)}
$$

For the perspective of the reversed border, the most efficient unit will be one that can produce many of all their outputs and spend a little of all their inputs, not stand out in any particular. It can be stated that the objective methodology to exclude the falsely efficient units from the group of efficient DMUs (ALMEIDA; MARIANO; REBELATTO, 2007).

It is observed that, with the application of the reversed border, it is also possible to sort the analyzed DMUs according to the measurement value of the normalized composed efficiency.

\section{RESULTS AND DISCUSSION}

\section{Selection of factors for evaluation of DMUs}

To analyze the proposed nine factors is recommended to evaluate at least 45 DMUs. Because only 33 DMUs were proposed, it may be necessary to reduce the amount of factors. For this reduction, the multi-criteria method was applied in order to select the main factors to perform the analysis.

The efficiencies calculations were performed using the computer tool SIAD (Integrated System of Decision's Support), described in Ângulo Meza et al. (2005).

The first stage of the multi-criteria method was the choice of the initial pair, input/output. Seeking a rationale for this choice, we chose to select the pair that showed the biggest value of the $\mathrm{S}$ term, calculated from the Equation 11, using $\alpha=0.5$, giving the same weight to both border settings, given by the average efficiency (SEF) as the maximum discrimination, given by the amount of efficient units (SDIS). 
In this stage, the DEA program (BCC model with orientation to the output) was executed for each pair input/output, determining the efficiency of the analyzed DMUs. Then, as there are seven inputs and two outputs, were got a total of 14 combinations, listed in Table 2, with the respective values of average efficiency, indicated $\mathrm{Ef}_{\text {média }}$, the number of efficient units, indicated by $\mathrm{N}^{\mathrm{o}}$ efic, and the terms SEF SDIS and S.

According to Table 2, it can be seen that the pair formed by the input VOT and CFT output showed the biggest value for the term $\mathrm{S}$, equivalent to 0.8210 . This pair showed an average efficiency for the whole analyzed set considered equivalent to $19.87 \%$, with two considered effective DMUs.

With the initial pair chosen, the next step of the multi-criteria method was to add another factor to the model, input or output, and then the DEA program was executed, calculating then the efficiency of the entire set of DMUs, as available in Table 3, which presents the data for all possible combinations of the second stage of the multi-criteria method.

It is added to the model NUO input factor. Thus, the model now has two inputs, NUO and VOT, and one output, CFT. This combination had an average efficiency of the entire DMUs set equivalent to $21.08 \%$, with three efficient units. Because the

Table 2. First stage of the multi-criteria method.

\begin{tabular}{lccccc}
\hline \multicolumn{1}{c}{ Pair } & Ef $_{\text {média }}$ & N $^{\mathbf{o}}$ efic & SEF & SDIS & S \\
\hline NTCxCFT & 0.1987 & 2 & 0.6417 & 1.0000 & 0.8208 \\
NTCxCAT & 0.1885 & 2 & 0.6089 & 1.0000 & 0.8044 \\
NUFxCFT & 0.1964 & 2 & 0.6343 & 1.0000 & 0.8172 \\
NUFxCAT & 0.1871 & 2 & 0.6043 & 1.0000 & 0.8021 \\
NUOxCFT & 0.1307 & 3 & 0.4221 & 0.5000 & 0.4610 \\
NUOxCAT & 0.1243 & 3 & 0.4015 & 0.5000 & 0.4507 \\
VCTxCFT & 0.2259 & 3 & 0.7297 & 0.5000 & 0.6149 \\
VCTxCAT & 0.1978 & 3 & 0.6387 & 0.5000 & 0.5694 \\
VOTxCFT & $\mathbf{0 . 1 9 8 7}$ & $\mathbf{2}$ & $\mathbf{0 . 6 4 1 9}$ & 1.0000 & $\mathbf{0 . 8 2 1 0}$ \\
VOTxCAT & 0.1913 & 3 & 0.6178 & 0.5000 & 0.5589 \\
DEHxCFT & 0.3096 & 4 & 1.0000 & 0.0000 & 0.5000 \\
DEHxCAT & 0.2808 & 4 & 0.9052 & 0.0000 & 0.4526 \\
DIHxCFT & 0.1366 & 2 & 0.4412 & 1.0000 & 0.7206 \\
DIHxCAT & 0.1292 & 2 & 0.4174 & 1.0000 & 0.7087 \\
\hline
\end{tabular}

$\mathrm{Ef}_{\text {média }}$ the a average effiiency; $\mathrm{N}^{\circ}$ efic the a number of effiient units; SEF is the standardize effiiency; SDIS is the standardize discrimination; $\mathrm{S}$ is the weighted sum of SEF and SDIS.

Source: Authors.

Table 3. Second stage of the multi-criteria method.

\begin{tabular}{cccccc}
\hline (VOTxCFT) & Ef $_{\text {média }}$ & $\mathbf{N}^{\mathbf{0}}$ efic & SEF & SDIS & S \\
\hline NTC & 0.2643 & 5 & 0.7097 & 0.3333 & 0.5215 \\
NUF & 0.2996 & 5 & 0.8043 & 0.3333 & 0.5688 \\
NUO & $\mathbf{0 . 2 1 0 8}$ & $\mathbf{3}$ & $\mathbf{0 . 5 6 6 1}$ & $\mathbf{1 . 0 0 0 0}$ & $\mathbf{0 . 7 8 3 1}$ \\
VCT & 0.3223 & 5 & 0.8654 & 0.3333 & 0.5993 \\
DEH & 0.3624 & 6 & 1.0000 & 0.0000 & 0.5000 \\
DIH & 0.2890 & 5 & 0.7760 & 0.3333 & 0.5547 \\
CAT & 0.2054 & 3 & 0.5514 & 1.0000 & 0.7757 \\
\hline
\end{tabular}

$\mathrm{Ef}_{\text {media }}$ the a average effiiency; $\mathrm{N}^{\circ}$ efic the a number of effiient units; SEF is the standardize effiiency; SDIS is the standardize discrimination; $\mathrm{S}$ is the weighted sum of SEF and SDIS.

Source: Authors. amount of factors, three in total, is lower than one fifth of the amount of DMUs, another factor must be added.

Continuing the multi-criteria method procedure, one more factor is added to NUOxCFTxVOT set, running, then the program that had the biggest value for the $\mathrm{S}$ term, equivalent to 0.7884 for the NUOxCFTxVOTxCAT combination with an average efficiency of the set of DMUs equal to $21.76 \%$ and four units considered efficient.

As the amount of template factors, altogether four, is less than one fifth of the number of evaluated units, the procedure continues. Adding one more factor to the evaluation model and afterwards calculating the average efficiencies of each simulation, we obtain that the NUF input factor can be added to the evaluation model. In this way, the model is now composed of five factors, three inputs, NUF, NUO and VOT, and two outputs, CFT and CAT. It is possible to observe that this combination showed an average efficiency for the analyzed DMUs set equivalent to $30.71 \%$, with five DMUs present on the efficient border.

As the amount of model factors, remains less than one fifth of the number of analyzed units, the procedure continues. Therefore, adding one more input factor to the evaluation model and after that calculating the average efficiencies of each simulation, it is observed that the NTC input factor can be added to the evaluation model. So, the model is now composed of six factors, four inputs, NTC, NUF, NUO and VOT, and two outputs, CFT and CAT. This combination had an average efficiency for the DMUs set equivalent to $30.71 \%$ and five DMUs considered effective.

The amount of model factors, NTCxNUFx NUOxVOTxCFTxCAT, is less than the one fifth of the number of DMUs from the analyzed set. However, if one more factor would be adde that model would have seven factors, which is higher than one fifth of the number of DMUs set. Thus, it was decided to finalize the selection process of variables for the model at this stage. Then, in Chart 3 is shown the final model for the evaluation of DMUs in this study.

\section{Calculation of efficiencies of DMUs}

Using the BCC model of the DEA, with an orientation to the output, it is possible to calculate the efficiency measurement for each DMU considering the set of selected factors. So, Table 4 shows the obtained values to measures of the relative efficiency of each analyzed unit.

Chart 3. Selected factors for the evaluation of DMUs.

\begin{tabular}{|c|c|}
\hline Inputs & Output \\
\hline - Total number of registered & - Total billed charge during the \\
\hline - Number of billed users (NUF); & - Total collected charge during \\
\hline $\begin{array}{l}\text { - Number of users granted from } \\
\text { the billed (NUO); }\end{array}$ & the period, in R\$/year, (CAT). \\
\hline $\begin{array}{l}\text { - Total consumed volume during } \\
\text { the period in } \mathrm{m} 3 \text { / year, (VCT); }\end{array}$ & \\
\hline $\begin{array}{l}\text { - total granted volume per year in } \\
\text { m3/year (VOT); }\end{array}$ & \\
\hline
\end{tabular}


Multicriteria Method in Data Envelopment Analysis: an application to measure the performance of the instrument of charging for water in the State of Ceará basins

Table 4. Measures of relative efficiency for each UMD of the analyzed set.

\begin{tabular}{llllll}
\hline DMU & Ef $_{\text {conv }}$ & DMU & Ef $_{\text {conv }}$ & DMU & Ef $_{\text {conv }}$ \\
\hline DMU1 & $\mathbf{1 . 0 0 0 0}$ & DMU12 & 0.3260 & DMU23 & 0.1570 \\
DMU2 & $\mathbf{1 . 0 0 0 0}$ & DMU13 & 0.2245 & DMU24 & 0.0022 \\
DMU3 & 0.0771 & DMU14 & 0.0852 & DMU25 & $\mathbf{1 . 0 0 0 0}$ \\
DMU4 & 0.2506 & DMU15 & 0.0181 & DMU26 & 0.1095 \\
DMU5 & 0.0864 & DMU16 & 0.2837 & DMU27 & 0.8336 \\
DMU6 & 0.0071 & DMU17 & 0.1834 & DMU28 & 0.1614 \\
DMU7 & 0.0381 & DMU18 & 0.0102 & DMU29 & 0.1980 \\
DMU8 & 0.0416 & DMU19 & $\mathbf{1 . 0 0 0 0}$ & DMU30 & 0.0056 \\
DMU9 & 0.0070 & DMU20 & 0.1864 & DMU31 & 0.9999 \\
DMU10 & $\mathbf{1 . 0 0 0 0}$ & DMU21 & 0.0013 & DMU32 & 0.1285 \\
DMU11 & 0.3195 & DMU22 & 0.3855 & DMU33 & 0.0072 \\
\hline EF is the the arithmetic average of effiiency in relation to the DEA \\
conventional border. \\
Source: Authors.
\end{tabular}

The DEA-BCC model applied provided five units considered efficient, while the remaining 28 are considered inefficient. In that way, the efficient units (benchmarks) are as follow:

- DMU1, which represents the industry's charge of the Metropolitana basin;

- DMU2, which represents the charge of the public supply of the Metropolitana basin;

- DMU10, which represents the industry's charge of the Middle Jaguaribe basin;

- DMU19, which represents the industry's charge of the Litoral basin;

- DMU25, which represents the industry's charge of the Coreaú basin.

From the five efficient DMUs, four are from the industry sector, while one represents the charge for water in the supply sector. We still highlight the DMU31 unit, which represents the industry's charge of the Banabuiú basin, with an efficiency measurement equivalent to 0.9999 (99.99\%), being considered almost efficient.

The units DMU24, irrigation charge of the Acaraú basin, and DMU2, irrigation charge of the Litoral basin, are the most inefficient units of the group (getting the last two positions), with efficiency measurements equivalent to $0.0022(0.22 \%)$ and 0.0013 $(0.13 \%)$, respectively.

In a general context of all State basins, the units representing the water charge in the industry sector had better performances than other sectors of supply and irrigation. In other words, the DMUs of the industry had the highest efficiency measurements of the whole group. In Table 5 the measurements of the average efficiency of each user sector are shown.

Thus, the charge for water industry had the highest average efficiency, followed by the charge of public supply and the last the charge of irrigation. A more detailed study may reveal if there is any particular feature that justifies this.

It is possible to observe, through the Appendix A, the units of industry and supply had the highest billed values (CFT) and raised (CAT) values with the charge for water in the considered
Table 5. Average efficiency measurements by user sector.

\begin{tabular}{lc}
\hline \multicolumn{1}{c}{ User sector } & Average efficiency \\
\hline Industry & 0.5767 \\
Public supply & 0.2269 \\
Irrigation & 0.1178 \\
\hline
\end{tabular}

Source: Authors.

period, while irrigation units had much lower values for the billing and the raising.

Thus, as the DEA-BCC model was oriented to the output, then the values of the CFT and CAT factors are quite relevant for the calculation of the efficiency measurements of the group.

The industry and public supply units have average values for outputs, CFT and CAT, similar. So, what makes the industrial units most efficient than the supply units are small input values, in particular the VOT (granted volume by sector).

The industry showed an average of 5.3 million $\mathrm{m}^{3}$ granted for the period, while the supply had 30.9 million per $\mathrm{m}^{3}$. It means the industry with less granted volume billed and consequently, collected values equivalents to the supply, with the charge for water.

But the irrigation sector had an average granted volume equal to 5.3 million $\mathrm{m}^{3}$, similar to the industry, however the billing and the collection was somewhere around 3 to $4 \%$ of the industry sector.

As an observed result, we notice that industry units achieved efficiency measurements higher than the units of the other sectors. It means, with high values for CFT and CAT outputs, while presenting lower values for VOT input, the industry DMUs showed better performance than the others.

It is important to stand out that the rates charged in the industry sector are higher than the rates of other sectors considered in the research. This fact can be considered very relevant to the obtained result, because the considered outputs (CFT and CAT) depend directly or indirectly on the amount of fees charged by water.

The DEA-BCC model also suggests goals to be achieved in the factors of each inefficient DMU, so that it reaches $100 \%$ of efficiency, and the lower the value of the efficiency measurement, the bigger are suggested adjustments.

That way, the inputs (NTC, NUF, NUO and VOT) are minimized, while outputs (CFT and CAT) are maximized. So, further suggested adjustments by the model were observed in the output factors, since a model with guidance to the output was chosen. It is worth to mention that the DEA methodology only suggests adjustments to be made in the factors of each DMU, however, nothing can be said if these adjustments can actually be put into practice.

In general, it can be said that the best performances were achieved by the DMUs that had bigger values for the outputs, CFT and CAT, and smaller values for the inputs, especially the VOT input.

Can not forget still to emphasize the fact that the units of the Metropolitana basin industry and the public supply, respectively DMU1 and DMU2, performed efficient, especially due to the fact that they present the highest values for CFT and CAT.

Statistically, it can be considered that the obtained data from CFT and CAT factors for DMU1 DMU2 units, when compared 
with the data of the other units are outliers. In that way, it is likely that the removal of these two units do not change significantly the overall result obtained in the research.

Following this, it will be applied the reversed border methodology to identify, among the five efficient DMUs, those which have a false efficiency.

\section{Application of the reversed border}

In the reversed border methodology, the inputs and outputs are reversed, and then we apply the DEA-BCC model with an orientation to the input. Shortly, in Table 6, data are presented to determine the normalized composed efficiency, indicated by Ef ${ }_{\text {norm }}$, beyond the position of each DMU, according to the measurement.

According to the data in Table 6, the most efficient unit is the DMU19, which represents the charge of the industrial sector in the Litoral basin. The DMU unit, which represents the charge

Table 6. Efficiency Measurement of the analyzed units.

\begin{tabular}{lccccc}
\hline DMU & Ef $_{\text {conv }}$ & Ef $_{\text {inv }}$ & Ef $_{\text {comp }}$ & Ef $_{\text {norm }}$ & Position \\
\hline DMU1 & 1.0000 & 1.0000 & 0.5000 & 0.5002 & $16^{\mathrm{a}}$ \\
DMU2 & 1.0000 & 1.0000 & 0.5000 & 0.5002 & $17^{\mathrm{a}}$ \\
DMU3 & 0.0771 & 0.0810 & 0.4980 & 0.4983 & $18^{\mathrm{a}}$ \\
DMU4 & 0.2506 & 0.1768 & 0.5369 & 0.5371 & $12^{\mathrm{a}}$ \\
DMU5 & 0.0864 & 0.0771 & 0.5046 & 0.5049 & $15^{\mathrm{a}}$ \\
DMU6 & 0.0071 & 1.0000 & 0.0035 & 0.0035 & $30^{\mathrm{a}}$ \\
DMU7 & 0.0381 & 0.8204 & 0.1088 & 0.1089 & $26^{\mathrm{a}}$ \\
DMU8 & 0.0416 & 1.0000 & 0.0208 & 0.0208 & $27^{\mathrm{a}}$ \\
DMU9 & 0.0070 & 1.0000 & 0.0035 & 0.0035 & $31^{\mathrm{a}}$ \\
DMU10 & 1.0000 & 0.0280 & 0.9860 & 0.9864 & $2^{\mathrm{a}}$ \\
DMU11 & 0.3195 & 0.0153 & 0.6521 & 0.6524 & $6^{\mathrm{a}}$ \\
DMU12 & 0.3260 & 0.0388 & 0.6436 & 0.6439 & $7^{\mathrm{a}}$ \\
DMU13 & 0.2245 & 0.4603 & 0.3821 & 0.3823 & $22^{\mathrm{a}}$ \\
DMU14 & 0.0852 & 0.0942 & 0.4955 & 0.4957 & $19^{\mathrm{a}}$ \\
DMU15 & 0.0181 & 0.4101 & 0.3040 & 0.3041 & $23^{\mathrm{a}}$ \\
DMU16 & 0.2837 & 1.0000 & 0.1418 & 0.1419 & $25^{\mathrm{a}}$ \\
DMU17 & 0.1834 & 0.0878 & 0.5478 & 0.5481 & $11^{\mathrm{a}}$ \\
DMU18 & 0.0102 & 1.0000 & 0.0051 & 0.0051 & $28^{\mathrm{a}}$ \\
DMU19 & $\mathbf{1 . 0 0 0 0}$ & $\mathbf{0 . 0 0 0 9}$ & $\mathbf{0 . 9 9 9 5}$ & 1.0000 & $1^{\mathrm{a}}$ \\
DMU20 & 0.1864 & 0.0123 & 0.5870 & 0.5873 & $8^{\mathrm{a}}$ \\
DMU21 & 0.0013 & 1.0000 & 0.0007 & 0.0007 & $33^{\mathrm{a}}$ \\
DMU22 & 0.3855 & 0.0528 & 0.6664 & 0.6667 & $5^{\mathrm{a}}$ \\
DMU23 & 0.1570 & 0.1764 & 0.4903 & 0.4905 & $20^{\mathrm{a}}$ \\
DMU24 & 0.0022 & 1.0000 & 0.0011 & 0.0011 & $32^{\mathrm{a}}$ \\
DMU25 & 1.0000 & 0.0977 & 0.9511 & 0.9516 & $3^{\mathrm{a}}$ \\
DMU26 & 0.1095 & 0.0687 & 0.5204 & 0.5206 & $14^{\mathrm{a}}$ \\
DMU27 & 0.8336 & 1.0000 & 0.4168 & 0.4170 & $21^{\mathrm{a}}$ \\
DMU28 & 0.1614 & 0.0544 & 0.5535 & 0.5537 & $10^{\mathrm{a}}$ \\
DMU29 & 0.1980 & 0.0259 & 0.5860 & 0.5863 & $9^{\mathrm{a}}$ \\
DMU30 & 0.0056 & 0.7177 & 0.1439 & 0.1440 & $24^{\mathrm{a}}$ \\
DMU31 & 0.9999 & 0.1458 & 0.9270 & 0.9274 & $4^{\mathrm{a}}$ \\
DMU32 & 0.1285 & 0.0631 & 0.5327 & 0.5330 & $13^{\mathrm{a}}$ \\
DMU33 & 0.0072 & 1.0000 & 0.0036 & 0.0036 & $29^{\mathrm{a}}$ \\
\hline If & & & & &
\end{tabular}

Ef is the arithmetic average of effiiency in relation to the DEA conventional border; $\mathrm{Ef}_{\text {inv }}$ is the complement of effiiency in relation to the reversed border; $\mathrm{Ef}_{\text {comp }}$ is the composed effiiency index; $\mathrm{Ef}_{\mathrm{norm}}$ is the normalization of the composed effiiency.

Source: Authors. of the industrial sector of the middle Jaguaribe basin, and UMD25 unit, which represents the charge of the industrial sector of the Coreaú basin, they remain in the first positions of the ranking, occupying the 2 nd and 3 rd place, respectively.

The reversed border method also identified the units DMU1, charge of the industrial sector in the Metropolitana basin and DMU2, charge of public supply in the Metropolitana basin as having false efficiencies. The DMU1 and DMU2 started to occupy respectively the 16 th and 17 th position.

Confirming the result obtained previously, the charges from the irrigation sector in the Acaraú basin, DMU24, and Litoral, DMU21, occupied the penultimate (32nd) and the last position (33th) of the evaluated group.

In general, it is possible to see that the units representing the instrument charging of industry sector occupy the top ranking positions, while the units representing the charging of the irrigation sector occupy the last positions.

\section{CONCLUSIONS}

The use of DEA for the charge for water reached the goal which was to obtain a diagnosis of all state watersheds, while the reversed border method ordered all analyzed DMUs.

It is important to detach that for the accomplishment of this evaluation the most significant factors were selected through the multi-criteria method. From the nine proposed factors for the evaluation, only six were selected through multi-criteria method, being four inputs (NTC, NUF, NUO and VOT) and two outpus (CFT and CAT).

Thereafter, the initial analysis indicated that from the 33 evaluated units, five are classified as efficient, being four from the industry and one from the public supply, and 28 were rated as inefficient.

The reversed border methodology showed that the charge of the industrial sector of the Litoral basin, DMU19, performed with excellent performance, the most efficient unit of the analyzed group.

The charge of the industry sector had the best performance in comparison to the other categories, with an average efficiency of $57.67 \%$, followed by supply, with the measurement of an average efficiency of $22.69 \%$, while the charge of irrigation proved with an average efficiency equal to $11.78 \%$, with the worst performance.

Altogether, the overview found in this study was also confirmed in the works of Rodrigues (2014) and Rodrigues, Aquino and Thomaz (2015). The units related to the charge of the industrial sector in the water basins of the State of Ceará proved with better results than the others, while irrigation obtained the worst results.

The charge of water is a vital management tool to ensure the balance between the offer and the demand for water in the river basins. Thus, the DEA can be applied to assist managers in evaluating this balance, so that we can have a rational use of water and that all users have been assured of their rights to access this resource.

It is possible to observe that the rates charged for the use of raw water in a particular use sector, excluding the Metropolitan Region of Fortaleza, can be considered constant in all Ceará basins. Therefore, the DEA can be used to help studies aiming to analyze 
the implementation of a possible distinction of rates, considering the peculiarities of each basin of the state.

Finally, as the research used data for a period of 12 months, the mentioned study has restrictions. Thus, to obtain a wider diagnosis it is recommended that you use the data related to a longer period of time.

\section{REFERENCES}

ADLER, N.; YAZHEMSKY, E. Improving discrimination in data envelopment analysis: PCA-DEA or variable reduction. European Journal of Operational Research, v. 202, n. 1, p. 273-284, 2010. http:// dx.doi.org/10.1016/j.ejor.2009.03.050.

ALMEIDA, M. R.; MARIANO, E. B.; REBELATTOO, D. A. N. Análise de eficiência dos aeroportos internacionais. Revista Produção Online, v. 7, p. 1-17, 2007. Disponível em: <https:// producaoonline.-org.br/rpo/article/view/51/51>. Acesso em: 4 mar. 2016.

ALPER, D.; SINUANY-STERN, Z.; SHINAR, D. Evaluating the efficiency of local municipalities in providing traffic safety using data envelopment analysis. Accident; Analysis and Prevention, v. 78, p. 39-50, 2015. PMid:25744172. http://dx.doi.org/10.1016/j. aap.2015.02.014.

ÂNGULO MEZA, L.; BIODINI NETO, L.; SOARES DE MELLO, J. C. C. B.; GOMES, E. G. Sistema ISYDS - Integrated System for Decision Support (SIAD - Sistema Integrado de Apoio à Decisão): a software package for data envelopment analysis model. Pesquisa Operacional, v. 25, n. 3, p. 493-503, 2005.

ÂNGULO MEZA, L.; SOARES DE MELLO, J. C. C. B.; GOMES, E. G.; FERNANDES, A. J. S. Selecção de variáveis em DEA aplicada a uma análise do mercado de energia eléctrica. Investigação Operacional, v. 27, n. 1, p. 21-36, 2007.

AQUINO, T. S. A.; GOMES, C. C.; SOUZA FILHO, F. A. Impacto da recuperação do investimento em infraestrutura hídrica na cobrança pelo uso da água. Revista Brasileira de Recursos Hidricos, v. 18, n. 1, p. 87-98, 2013. http://dx.doi.org/10.21168/ rbrh.v18n1.p87-98.

ATHANASSOPOULOS, A. D. Discriminating among relatively efficient units in data envelopment analysis: A comparison of alternative methods and some extensions. American Journal of Operations Research, v. 2, n. 1, p. 1-9, 2012.

BANAEIAN, N.; OMID, M.; AHMADI, H. Application of data envelopment analysis to evaluate efficiency of commercial greenhouse strawberry. Research Journal of Applied Sciences Engineering and Technology, v. 3, n. 3, p. 185-193, 2011.

BANKER, R. D.; CHARNES, A.; COOPER, W. W. Some models for estimating technical and scale inefficiencies in data envelopment analysis. Management Science, v. 30, n. 9, p. 1078-1092, 1984.
BARBOSA, R. P.; BASTOS, A. P. V. Utilização da análise por envoltória de dados (DEA) na mensuração da eficiência das prestadoras de serviços de água e esgotamento sanitário: Um enfoque no desempenho da companhia de saneamento do estado do Pará. Revista Economia \& Gestão, v. 14, n. 35, p. 151-181, 2014.

CEARÁ. Decreto no 31.195, de 16 de abril de 2013. Diário Oficial do Estado, Fortaleza, CE, 18 abr. 2013. Disponível em: <http:// www.srh.ce.gov.br/index.php?option $=$ com_phocadownload\&vi $\mathrm{ew}=$ category\&id $=159$ : decretos $\&$ Itemid $=301 \& \mathrm{tmpl}=$ componen t\&print $=1>$. Acesso em: 18 mar. 2016.

CHARNES, A.; COOPER, W. W.; RHODES, E. Measuring the efficiency of decision making units. European Journal of Operational Research, v. 2, n. 6, p. 429-444, 1978.

CHERCHYE, L.; ROCK, B.; WALHEER, B. Multi-output profit efficiency and directional distance functions. Omega, v. 61, p. 100109, 2016.

DOTOLI, M.; EPICOCO, N.; FALAGARIO, M.; SCIANCALEPORE, F. A cross-efficiency fuzzy data envelopment analysis technique for performance evaluation of decision making units under uncertainty. Computers \& Industrial Engineering, v. 79, p. 103-114, 2015.

FINKLER, N. R.; MENDES, L. A.; BORTOLIN, T. A.; SCHNEIDER, V. E. Cobrança pelo uso da água no Brasil: Uma revisão metodológica. Desenvolvimento e Meio Ambiente, v. 33, p. 33-49, 2015.

GOMES JÚNIOR, S. F.; SOARES DE MELLO, J. C. C. B.; ÂNGULO MEZA, L. DEA nonradial efficiency based on vector properties. International Transactions in Operational Research, v. 20, p. 341-364, 2013.

HONGLAN, L.; RUYUN, Y.; XIAONA, Q. Productivity analysis and benchmark selection of X mining company by DEA. Journal of Chemical and Pharmacentical Research, v. 6, n. 4, p. 162-168, 2014.

MIRDEHGHAN, S. M.; FUKUYAMA, H. Pareto-Koopmans efficiency and network DEA. Omega, v. 61, p. 78-88, 2016.

PARK, J.; YOO, S. K.; LEE, J. S.; KIM, J.; KIM, J. J. Comparing the efficiency and productivity of construction firms in China, Japan and Korea using DEA and DEA based malmquist. Journal of Asian Architectures and Building Engineering, v. 14, n. 1, p. 57-64, 2015.

PEREIRA, E. R.; SILVEIRA, J. Q.; CHAVES, M. C. C. Eficiência de empresas aéreas: Uma análise baseada no modelo de Li \& Reeves. Journal of Transport Literature, v. 6, n. 2, p. 105-123, 2012.

PÉRICO, A. E.; REBALATTO, D. A. N.; SANTANA, N. B. Eficiência bancária: Os maiores bancos são os mais eficientes? Uma análise por envoltória de dados. Revista Gestão \& Producão, v. 15, n. 2, p. 412-431, 2008.

PRADHAN, A. K.; KAMBLE, A. A. Efficiency measurement and benchmarking: An application of data envelopment analysis 
to select multi brand retail firms in India. Journal of Commerce \& Management Thought, v. 6, n. 2, p. 258-272, 2015.

QINGXIAN, A.; YAN, H.; LIANG, L. Internal resource waste and centralization degree in two-stage systems: an efficiency analysis. Omega, v. 61, p. 89-99, 2016. http://dx.doi.org/10.1016/j. omega.2015.07.009.

RODRIGUES, M. V. S. Avaliação do desempenho da cobrança da água bruta por categoria de uso nas bacias do Estado do Ceará utilizando a análise por envoltória de dados. 2014. 174 f. Tese (Doutorado em Engenharia Civil) - Centro de Tecnologia, Universidade Federal do Ceará, Fortaleza, 2014.

RODRIGUES, M. V. S.; AQUINO, M. D. Análise comparativa entre a cobrança pelo uso da água bruta do Estado do Ceará com a cobrança aplicada no Estado de São Paulo. Revista de Gestão de Águas da América Latina, v. 11, n. 2, p. 37-51, 2014.

RODRIGUES, M. V. S.; AQUINO, M. D.; THOMAZ, A. C. F. Análise por envoltória de dados utilizada para medir o desempenho relativo da cobrança pelo uso da água nas bacias hidrográficas do estado do Ceará. Revista de Gestão de Águas da América Latina, v. 12, n. 1, p. 15-29, 2015.

SILVEIRA, G. L.; FORGIARINI, F. R.; GOLDENFUM, J. A. Taxa não é cobrança: Uma proposta para a efetiva aplicação do instrumento de gestão dos recursos hídricos para a drenagem urbana. Revista Brasileira de Recursos Hídricos, v. 14, n. 4, p. 71-80, 2009.

SOARES DE MELLO, J. C. C. B.; GOMES, E. G.; ÂNGULO MEZA, L.; LINS, M. P. E. Selección de variables para el incremento del poder de discriminación de los modelos DEA. Revista de la Escuela de Perfeccionamiento En Investigación Operativa, v. 24, p. 40-52, 2004.

\section{Authors contributions}

Marcus Vinicius Sousa Rodrigues: Contributed bibliographical research, data analysis, processing and simulations, writing.

Marisete Dantas de Aquino: Contributes with her orientation, indications of bibliographical references and analysis of the results related to the hydrographic basins.

Antônio Clécio Fontelles Thomaz: Contributed to his co-orientation, indications of bibliographical references, and analysis of the results of the wrappings.

Rejane Felix Pereira: Contributed to analysis of the results, data collection, review and formatting of the article. 
Appendix A. Data factors of each decision making unit.

\begin{tabular}{|c|c|c|c|c|c|c|c|c|c|}
\hline DMU & NTC & NUF & NUO & $\begin{array}{c}\text { VCT } \\
\left(\mathrm{m}^{3} / \text { year }\right) \\
\end{array}$ & $\begin{array}{c}\text { VOT } \\
\left(\mathrm{m}^{3} / \text { year) }\right.\end{array}$ & $\begin{array}{c}\text { DEH } \\
\left(\mathrm{m}^{3} / \text { year }\right)\end{array}$ & $\begin{array}{c}\mathrm{DIH} \\
\left(\mathrm{m}^{3} / \text { year }\right)\end{array}$ & $\begin{array}{c}\text { CFT } \\
\text { (R\$/ year) }\end{array}$ & $\begin{array}{c}\text { CAT } \\
\text { (R\$/ year) }\end{array}$ \\
\hline DMU1 & 188 & 121 & 63 & $21,201,494.13$ & $55,789,465.63$ & 7.99 & 20.62 & $29,866,171.45$ & $29,325,593.75$ \\
\hline DMU2 & 103 & 42 & 29 & $281,970,523.29$ & $168,885,538.17$ & 7.48 & 20.62 & $28,223,806.33$ & $27,712,955.44$ \\
\hline DMU3 & 90 & 48 & 6 & $17,302,943.33$ & $3,875,277.43$ & 0.74 & 20.62 & $175,603.94$ & $172,425.51$ \\
\hline DMU4 & 40 & 40 & 7 & $156,165.73$ & $17,395.90$ & 0.23 & 11.82 & $67,395.03$ & $46,799.11$ \\
\hline DMU5 & 30 & 14 & 13 & $9,038,515.89$ & $8,400,609.74$ & 0.31 & 11.82 & $296,192.18$ & $205,675.85$ \\
\hline DMU6 & 159 & 25 & 11 & $22,654,909.29$ & $20,837,779.08$ & 2.63 & 11.82 & $44,633.69$ & $30,993.63$ \\
\hline DMU7 & 24 & 19 & 9 & $25,577.26$ & $56,272.05$ & 0.11 & 21.74 & $11,038.14$ & $6,168.11$ \\
\hline DMU8 & 77 & 21 & 20 & $15,021,544.23$ & $66,858,257.97$ & 0.35 & 21.74 & $492,255.98$ & $275,072.64$ \\
\hline DMU9 & 75 & 25 & 10 & $2,655,018.85$ & $2,242,953.73$ & 0.45 & 21.74 & $10,248.18$ & $5,726.68$ \\
\hline DMU10 & 28 & 26 & 0 & $640,746.23$ & 0.00 & 0.05 & 31.88 & $276,520.40$ & $172,825.25$ \\
\hline DMU11 & 48 & 17 & 7 & $13,583,183.74$ & $2,160,509.40$ & 0.13 & 31.88 & $445,120.96$ & $278,200.60$ \\
\hline DMU12 & 107 & 73 & 4 & $149,909,007.51$ & $9,281,166.47$ & 4.90 & 31.88 & $889,856.13$ & $556,160.08$ \\
\hline DMU13 & 103 & 87 & 22 & $149,486.77$ & $29,064.50$ & 0.21 & 1.55 & $64,512.40$ & $43,010.42$ \\
\hline DMU14 & 38 & 7 & 6 & $5,226,680.00$ & $7,878,171.11$ & 0.23 & 1.55 & $171,278.31$ & $114,191.25$ \\
\hline DMU15 & 155 & 12 & 5 & $21,055,233.12$ & $5,285,521.51$ & 1.72 & 1.55 & $43,252.74$ & $28,836.60$ \\
\hline DMU16 & 76 & 60 & 46 & $583,954.33$ & $1,153,575.20$ & 0.15 & 6.44 & $252,011.30$ & $172,753.75$ \\
\hline DMU17 & 86 & 32 & 21 & $48,047,543.68$ & $22,256,012.08$ & 0.85 & 6.44 & $1,574,518.07$ & $1,079,332.14$ \\
\hline DMU18 & 213 & 12 & 4 & $8,932,232.08$ & $2,642,256.49$ & 2.53 & 6.44 & $16,618.23$ & $11,391.80$ \\
\hline DMU19 & 8 & 3 & 1 & $205,910.00$ & $150,211.53$ & 0.15 & 1.15 & $302,187.35$ & $293,031.07$ \\
\hline DMU20 & 22 & 6 & 3 & $6,545,175.87$ & $2,369,032.50$ & 0.20 & 1.15 & $214,485.37$ & $207,986.46$ \\
\hline DMU21 & 15 & 3 & 2 & $513,646.44$ & $218,111.74$ & 0.02 & 1.15 & 410.28 & 397.85 \\
\hline DMU22 & 58 & 53 & 9 & $681,287.10$ & $919,434.50$ & 0.06 & 12.39 & $294,611.26$ & $248,092.14$ \\
\hline DMU23 & 71 & 35 & 11 & $39,020,086.73$ & $37,092,185.73$ & 1.10 & 12.39 & $1,278,688.19$ & $1,076,783.33$ \\
\hline DMU24 & 19 & 10 & 2 & $934,976.11$ & $477,057.71$ & 6.21 & 12.39 & $1,095.52$ & 922.54 \\
\hline DMU25 & 15 & 12 & 0 & $75,389.47$ & 0.00 & 0.02 & 3.22 & $32,535.06$ & $14,458.58$ \\
\hline DMU26 & 15 & 6 & 5 & $4,283,941.04$ & $3,459,543.00$ & 0.50 & 3.22 & $140,384.72$ & $62,386.97$ \\
\hline DMU27 & 4 & 1 & 1 & $49,027.00$ & $2,075,700.63$ & 0.09 & 3.22 & 23.83 & 10.59 \\
\hline DMU28 & 14 & 13 & 1 & $89,622.00$ & $96,177.50$ & 0.01 & 6.94 & $38,677.26$ & $37,961.73$ \\
\hline DMU29 & 27 & 11 & 6 & $16,190,356.62$ & $7,029,251.10$ & 0.52 & 6.94 & $530,558.01$ & $520,742.69$ \\
\hline DMU30 & 61 & 26 & 8 & $9,567,450.32$ & $5,202,867.89$ & 0.00 & 6.94 & $16,582.35$ & $16,275.58$ \\
\hline DMU31 & 16 & 11 & 0 & $25,305.22$ & 0.00 & 0.23 & 21.66 & $10,920.71$ & $8,008.16$ \\
\hline DMU32 & 89 & 13 & 12 & $15,052,458.03$ & $13,410,396.71$ & 0.32 & 21.66 & $493,269.09$ & $361,714.22$ \\
\hline DMU33 & 162 & 87 & 23 & $15,407,150.77$ & $6,549,775.50$ & 8.75 & 21.66 & $26,996.31$ & $19,796.39$ \\
\hline
\end{tabular}

